\title{
The Impact of CRM on Customer Satisfaction and Customer Loyalty: Mediation Effect of Customer Perceived Value (Evidence from Hospitality Industry) ${ }^{1}$
}

\author{
Dr. Samia Adly El Sheikh ${ }^{2}$ \\ Prof. Hosny Ibrahim Hamdy4
}

Prof.Yasser Tawfik Halim ${ }^{3}$

Prof.Mohamed Adel Hamdy ${ }^{5}$

October University for Modern Scienes and Arts (MSA)

\begin{abstract}
Many businesses and service providers including hotels realize the significance of Customer Relationship Management (CRM) and its potential to help them gain new customers, retain existing customers, and maximize their lifetime value. This study aims to explore the relationship between CRM and customer perceived value (CPV), and their impact on customer perceived satisfaction and loyalty towards hotels in Egypt. The study clarifies the need for hotels to strengthen their business relationship with their customers as it is considered a strategic step for the growth and competitiveness of hotels. The contribution of this research is to help managers of hotels to better understand the real value of CRM and if it is really worth the large amounts of money that are put in it. Moreover, the study further added the investigation of whether CPV mediates the relationship between CRM and customer satisfaction/loyalty or not. The researchers adopted a quantitative approach that started with a comprehensive literature review of the main marketing concept of CRM and its alleged outcomes of customer perceived value (CPV), satisfaction and loyalty. This was followed by designing a conceptual model to answer the research questions. Next, primary data was gathered using self-administered questionnaires to collect quantitative data from several branches of one 5-star hotel in Egypt based
\end{abstract}

\footnotetext{
${ }^{1}$ Received in 6/6/2020, accepted in 13/10/2020.

${ }^{2}$ Lecturer,October University for Modern Sciences and Arts (MSA)(selsheikh@msa.eun.eg)

${ }^{3}$ Professor, October University for Modern Sciences and Arts (MSA) (ytawfik@msa.eun.eg) ${ }^{4}$ Professor, October University for Modern Sciences and Arts(MSA)(hosikhalel@ msa.eun. eg) ${ }^{5}$ Professor, October University for Modern Sciences and Arts (MSA) (adelhamdy@msa.eun.eg)
} 
on a case study approach. Structural Equation Modeling (SEM) technique was utilized to test the relationship between CRM and customer satisfaction and loyalty via l mediating variable which is CPV. Fitting measures prove to be within the required threshold, which proves that the model is fit. The results indicate that there is a positive significant relationship between CRM and CPV and that CRM positively affects customer satisfaction and loyalty, yet the researchers suggest application on other hotels to further test the model.

KeyWords:Customer relationship management (CRM), Customer Perceived Value (CPV), Customer Satisfaction, Loyalty, Hospitality Industry in Egypt, Structural Equation Modeling (SEM)

\section{INTRODUCTION}

To give a general idea about Customer relation management (CRM) the researchers started by a quote, "The more you know about your guest the more you can serve guest needs" a hotel expert once said. According to Kotler and Armstrong, (2017), in its broader meaning, CRM is the overall process of building and maintaining a profitable relationship with customers by offering outstanding value that leads to customer satisfaction and nurtures customer loyalty towards the brand or the organization. Yet in a more focused sense CRM is managing customer detailed information with the aim of increasing customer loyalty (Munandar, et al., 2020).

Many companies start by building advanced extensive storage of information about the market and detailed information about customers that can be accessed instantly by marketing managers. These advanced databases require highly sophisticated equipment and staff to handle this equipment. But the major challenge is how to use this wealth of information effectively in order to build a strong customer relationship to follow customers' spending trends that can be used to segment the customers and accordingly to tailor the market offering to create the best possible value for the customers. Smart companies capture information at every possible customer "touch point" that include customer purchases, contacts with sales force, contact with service center; call centers, website visits, satisfaction surveys, credit and payment interactions, market research studies; that is every contact with the customer. The problem is that this information could be scattered in 
different departments of the firm, thus not used efficiently and this is where the CRM systems step in to carefully manage various pieces of information about individual customers using advanced software and analytical tools to develop data warehouses and then apply sophisticated data mining techniques to analyze the rich information so as to get a $360^{\circ}$ view of the customer. The organization can use CRM to pinpoint highvalue customers in order to cross-sell other company products to them, target them personally and these premium "VIP" customers are provided with outstanding services as "no wait" service, extra benefits to guarantee their loyalty (Kotler and Armstrong, 2017).

In many hotels the operating system is built on having a guest profile which is kept updated by adding information that will support the hotel in knowing guest preferences. Hassanien and Dale (2019) states that many service providers such as insurance companies and hotels realize the significance of CRM and its ability to help them retaining their existing customers, acquire new ones, and maximize their lifetime value. In order to create a close relationship with customers, based on the coordination between the management and the IT department to ensure a long-term retention of selected customers. CRM is a reliable business strategy that helps identifying the most profitable prospects and customers, assigning time and effort to enhance relationships with those customers via individualized management, flexible decision making, and personalized services delivered through different sales channels that the hotel or any service providers uses.

This research deals with the role that CRM plays in the Egyptian hotel industry and the need for hotels to increase customer base, and to build a good long relationship with premium customers which leads to a favorable customer perceived value (CPV) which in turn leads to customer satisfaction and loyalty.

The aim of this research is to explore the relationship between CRM and customer perceived value (CPV), and their impact on customer perceived satisfaction and loyalty towards hotels in Egypt applied on branches of one 5 star hotel in Egypt on a case study basis. The researchers believe that tough competition, high customer expectations along with constant changes in demographics of guests and in the 
economic environment obligate hotels to rethink of their business' CRM practices and how to improve them to increase customer loyalty towards the hotel. All the activities and tasks performed by the hotel managers should revolve around maintaining a long-term relationship with customers because loyal customers are the main source of revenue to the business.

In this study the researchers investigate:

1- Does the implementation of CRM practices affect CPV?

2- Does CRM impact customer satisfaction and loyalty?

3- Does CPV mediate the relationship between CRM and customer satisfaction/loyalty?

The importance of this research lies in the fact that the area of application of the study is hospitality services which is part of the tourism sector and Egypt has a comparative advantage in tourism due to its natural beauty and its accessible location and old civilization monuments as well as its relatively fine weather; thus the Tourism industry has a considerable, unquestionable potential contribution to the growth of Egyptian economy. In 2018 Egypt received 11,347,000 tourists (source: Ministry of Tourism statistical year book) in addition to internal tourism of locals who spend their holidays and feast days in hotels. Satisfied customers will come back to the same hotel the next visit. Customer satisfaction in hotels has been based in many studies on service quality and perceived value which represent a competitive advantage for the hotel (Banki, et al., 2016; Fakharyan, et al., 2014). Hotels aim not only to satisfy customers but to do so better than their competitors in the increasingly competitive market of hotels in Egypt. Moreover, the tourism sector can involve layers of the population and create jobs for different careers. As such, tourism can enhance the economic conditions within the country. In Egypt the growth rate of tourism sector represents $37.7 \%$ in year 2017/2018. (Ministry of Administrative Reform and Planning). Yet with all factors of attraction available to Egyptian destination hotels the level of hotel occupancy of $34 \%$ is way lower than expected.

Although the Egyptian economy depends greatly on tourism, and tourism is considered to be one of the main sources of income in Egypt, still there is a lot to be done to improve our hospitality services to attract 
more guests (visitors) whether local or international and make their stay at the hotel as enjoyable and convenient as possible. In this study the researchers investigate how customers perceive the implementation of CRM. In Egypt, only 5 star hotels execute CRM programs which are quite expensive and require high tech equipment, which makes this study very important to determine the effects of CRM and help Egyptian hotels to compete globally with other hotels and improve the income of the Egyptian tourism sector. Therefore, the research investigates various attributes of CRM and how they generally affect customers in order to help enhancing the performance of hotels in Egypt. Thus the management of 5 star hotels in Egypt that apply CRM practices can make use of the empirical results of this research to enhance their understanding CRM impact on CPV and thus on customer satisfaction and loyalty needed to achieve highest revenue that can only be achieved when customers are satisfied and come back again. The value of satisfied customers cannot be overlooked as happy customers come back again, spread good word of mouth or positive e-word of mouth and act as free of charge advertising. Quite recently, the concept of customer relationship management (CRM) has come to the front stage as a solution to achieve customer satisfaction and customer loyalty.

From the review of literature, the researchers pinpointed a gap in literature which is that although many studies have investigated the impact of CPV on customer satisfaction and loyalty yet none according to the authors' humble knowledge have investigated the mediation role of CPV between CRM and its alleged outcomes of satisfaction and loyalty and this leads to the contribution of this study. Thus the authors assumed that the increase in CPV will change the effects of CRM on customer satisfaction and customer loyalty so they set forth the hypotheses related to the mediation role of CPV between CRM and its alleged outcomes of customer satisfaction and loyalty to test the indirect effects of CRM on Customer Satisfaction, Loyalty via CPV. The contribution of this research is to help managers of hotels to better understand the real value of CRM and if it is really worth the large amounts of money that are put in it. Moreover, the study further added the investigation whether CPV mediate the relationship between CRM and customer satisfaction/loyalty or not. The study offers significant 
contributions to the growing CRM, CPV, customer satisfaction and customer loyalty literature. It provides new empirical evidence that the CRM has a significant direct, indirect, and total effect on customer satisfaction and customer loyalty in the Egyptian hospitality industry. Our findings indicate that CPV plays a role in enhancing the relationship between CRM and customer satisfaction and customer loyalty. Thus the mediation effect strengthens the relationship between independent variable (predictor) CRM and its alleged outcomes of customer satisfaction and loyalty (dependent variables). Thus, the research contributes to practitioners by pinpointing the organization benefits of using the CRM with clearly understanding the CPV in order to cross-sell other company products to the selected customers, target them personally.

\section{THEORETICAL BACKGROUND}

\subsection{Customer Relationship Management (CRM) Definitions and dimensions}

\subsubsection{Definiton}

The researchers (authors) investigated several definitions and attributes of CRM. According to (Hollebeek, et al. 2019); (Nazir, et al. 2014) CRM consists of three concepts (customer, relationship and management). Customers are the main target of any organization so the organization should customize their products and services based on the customer's needs. (Wali, et al. 2016); Monga, and Kaplash, (2016) agree that managing business and customer relationships involves a process of acknowledging customer needs, and studying their purchase habits and preferences. To evaluate customer's consumption experiences the firm's employees interact with the customers on the telephone or face to face concerning enquiries or complaints. Moreover, Madhovi and Dhliwayo (2017) state that the tools of CRM include all the information about a customer, thus it requires to track customers and locate which ones will generate more profit compared to others and facilitates the understanding of different customers so that the company can then concentrate on each customer in a tailored way. Therefore, this is an indication that customers are the most important aspect in the firm's service delivery process. 
Relationship is the relation between the customer and the organization and how strong it is based on mutual interactions and connections and benefits, the stronger the relation between the customer and the organization the more profit and more loyal the customer will be. Management is how to manage the relation between the customer and the organization and how to improve it and retain the customer lifetime value.

\subsubsection{CRM dimensions}

Dewnarain, et al., (2018); Mohammed and Rashid (2012) argue that CRM is a multi- dimension concept which basically consists of several behavioral dimensions including CRM organization, knowledge management, customer engagement and technology-based CRM. These dimensions should be systematically implemented in hotels to ensure improved performance. They are as follows:

- CRM organization: Mohammed and Rashid (2012) stated that in order to ensure customer oriented behavior of employees, the organization has to develop a proper working environment for the service delivered, for example, providing staff with modern tools and technology, inspirational leadership and reward systems, customer satisfaction tracking and complaints management systems. CRM success does not only depend on technological systems, the service concept has to be effective and the operation procedures have to be suitable. Therefore, employees should be actively involved in the CRM process. In order to implement a successful CRM and improve organizational performance, the organization should integrate all its resources including policies, organization structure, culture, and marketing capabilities. Furthermore, CRM organization may influence the organization's future strategies, such as pricing, communication, distribution, and brand differentiation. In this regard, it was also declared that some hotels flexibly set their room prices according to the customer data that were gathered previously.

- Knowledge management: Hislop, et al., (2018); Madhovi and Dhliwayo (2017) pointed out that, an organization can collect information about its customers through cooperation with them in different ways. Managing knowledge properly can assist a company to successfully implement enhanced customer relations that can positively affect 
organizational performance. Pandey, (2012) mentioned that in current years' organizations have mixed their CRM with efforts of knowledge management as they concluded that it plays a main role in CRM achievement. Mohammed and Rashid (2012) reported that the success of any relationship management is highly dependent on the gathering and analyzing of customer information as such data will be used in creating extremely personalized offerings especially in the hospitality sector. It is reported that hotels with large customer knowledge data that can be distributed among their different departments are more likely to develop effective marketing activities to meet their customer needs.

- Customer engagement: Mohammed and Rashid (2012) stated that in service oriented organizations such as hotels, the delivery of service occurs when interaction happens between the service- providers and the customer at the service encounter at all points of touch with the customer. Thus, hotels need to focus on creating positive customer interaction in order to enhance customer experience. CRM activities are claimed to increase customer engagement with all its possible benefits to the brand. Customer engagement can be defined as the relationship between the customer and a brand or organization in which the customer manifests interest towards the brand that is accompanied by a behavior beyond the purchase behavior and this behavior is not planned by the organization but rather initiated by the customer from motivational drivers (El Sheikh, 2019). This extra mile by the customer in the hospitality industry takes the form of positive word of mouth (WOM) or e-WOM or favorable online reviews which in turn has its unmatched benefits that help to decrease the level of perceived customer risk or uncertainty in the customer's has an impact on behavioral intents of buyers (Bufquin, et al., 2019). According to Yen \& Tang, (2015) online reviews have a big influence on customers when buying high involvement intangible services as expensive stay in a luxury hotel. Positive WOM in the form of positive online reviews in a social media platform as Trip Advisor are a form of free of charge, credible advertising and this is a direct outcome of customer engagement. If customers don't have a good relationship on 
the basis of trust with the firm they would not be willing to exert efforts and engage in actions that benefit the firm (Itani, et al. 2019) .Thus CRM leads to customer engagement and customer engagement increases brand attraction to potential customers. According to (Ong, et al., 2018) the extremely tough competition in the hospitality industry emphasizes creating a very good relationship with the profitable customers which is ensured through CRM activities that will lead to brand loyalty.

- Technology based CRM: According to Pandey, (2012), the term technology based CRM refers to advanced information technology that assists various activities of CRM which leads to major opportunities in the hotel industry as it facilitates gathering the right information from the right people at the right time in order to make the right decisions in providing their service. New technologies are required in hotels as essential drivers for change to improve their performance. In other words, some studies declared that customer-centric strategies cannot be achieved without use of information technology.

Moreover, according to Emir et al., (2016) the evolution of internet technology has forced hotels to invest significant amounts of money and efforts to develop and maintain their own direct booking websites. The majority of hotel customers use internet to search for hotel information, therefore, it is crucial for the hotels to understand the factors influencing their customers' intention to book hotel accommodation online. Based on studies of online hotel booking, several variables were found to influence CPV. These include information quality, as per (Kurnia and Sulistiani, 2019); (while Abdullah, et al., 2019); and Leong, et al., (2019) emphasized perceived interactivity of the website that allows for reviews and E-WOM because when a hotel receives positive customer reviews, it experiences an increase in online room sales because services being intangible that is they cannot be experienced except after buying the service, thus hotel customers tend to minimize risk and uncertainty. Moreover, Agag, et al., (2019); Hu, and Yang, (2019) stressed safety and privacy as a critical variable that influences $\mathrm{CPV}$. 
Thus from the above the researchers set forth the following hypothesis that CRM has a direct impact on CPV:

Ha1: There is positive significant direct effect of CRM on CPV

\subsection{Customer Relationship Management (CRM) and Satisfaction}

Abbasi, et al. (2010); Dominici and Guzzo (2010) stated that the quality of the service and the customers' satisfaction are influenced by each other, delivering a high quality service results in customers' satisfaction which is the main factor to have a competitive advantage and customer retention in the hotel industry.

Hassanien and Dale, (2019); Avelini Holjevac, et al. (2009), stated that customer satisfaction of hotels depends on several factors that CRM can fulfill including providing consistent high quality services, protecting customer transactions within the hotel and complying with its obligations towards its customers. Moreover, hotels should always provide customers with what they need. Thus, customers will be less likely to switch to other hotels as long as they are happy and satisfied in dealing with the hotel (Halim and Halim, 2013).

CRM is the idea of managing the organization's customers, clients or potential sales and it highly depends on the use of technology to organize and synthesize all the processes of the business with the aim of improving customer satisfaction which eventually leads to increased profitability (Long et al., 2013).

From a different perspective, Ahmed, et al. (2019); Pandey (2012) stated that CRM refers to a business process that leads to generation of revenue and optimization of profit during attaining customer satisfaction. It was found that it is very important for the success of CRM system to be processed and oriented at a strategic level that connects the informational, operational as well as the organizational factors of CRM. Managers have to wisely differentiate between customer profitability and customer loyalty as there is a difference between managing customers for profits and managing them for loyalty. Moreover, it is a complete procedure and strategy of retaining, gaining and participating with special customers to inspire a good value for the organization. The innovation in data warehousing, information technology and data mining abilities allows 
organizations to administer individualized relationships with main customers.

Madhovi and Dhliwayo (2017); El Deeb, and Halim, (2010) added that the process of CRM facilitates the understanding and responding between businesses and their customers to instantly know the desire of the customers. CRM is a fundamental to understand what increases customer satisfaction which has a great effect on future customer behavior. There are some performance indicators that are believed to be positively influenced by CRM which are: market share, profitability, return on investment, and sales turn over. Moreover, Rahimi, (2017) reported that executing a CRM solution requires considerable money and time, however, it has various significant benefits. The primary benefits of CRM are increased customer satisfaction and customer retention which consequently lead to increased repeat purchase or visit. In many articles the relationship between firm and customer is theorized to increase satisfaction and loyalty (Kumar, 2020; Ruiz-Martínez, et al., 2019). These two outcomes are among the most heavily employed indicators of the intensity of customer-firm relationship (Gremler, et al., 2019; Sofi, et al., 2020). Madhovi and Dhliwayo (2017) pointed out that it is very important for hotel managers to implement CRM which, provides customization services for the customers which in turn ensures satisfaction. Thus, the utilization of CRM in hotel industry is very important because it is the main key for customers' satisfaction. AlWeshah, et al., (2019); Pandey, (2012), explain that CRM depends on four key stages which are recognition, re-evaluation, retention as well as revenue. Consequently, CRM begins with customers' recognition as it refers to a process that begins with identifying the profitable customers and sharing information with them as well as implementing a strong personal relationship with these key customers. In the stage of reevaluation, the consistent interaction with customers encourages them to re-evaluate their cooperation with the company. Retention is the state of keeping customers in the hotel for the longest time. Having a competitive advantage may extend the retention stage. Retention stage is very crucial to reach the revenue generation stage, in which satisfied customers will 
rarely think about switching from one company to another and are less susceptible to price connected service facilities and progressively turn into a center for generation of revenue.

From the above review, the authors hypothesized that CRM has a positive direct significant effect on Customer Satisfaction:

$\mathbf{H}_{\mathrm{a} 2}$ : There is positive significant direct effect of CRM on Customer Satisfaction

\subsection{Customer Relationship Management (CRM) and Loyalty}

According to Saleem and Raja (2014), customer loyalty is that customers have the intention to return to the same hotel again, which is behavioral loyalty, a loyal customer is the customer who repurchases from the service provider whenever possible and recommends the service to other customers with a good attitude and spreads a positive word of mouth and will have the willingness to pay even if the hotel raises its prices and this is attitudinal loyalty.

Nyadzayo and Khajehzadeh (2016) mentioned that the best measure of accomplishment in any company is customer loyalty. Loyal customers will assist the company to decrease marketing costs and increase its market share. Madhovi and Dhliwayo (2017) mentioned that in the past years many researchers while dealing with CRM, customer loyalty and service quality within the hotels recognized that a higher level of CRM leads to higher customer loyalty. In order for the hotel managers to manage customer relationship appropriately, they should build strategy, customer-centric practices and should adopt techniques and tools that enable them to implement long lasting and powerful relationship with customers. Wali,et al., (2016) explained that consumer commitment is a valid predictor of customer loyalty and it positively affects customer advocacy behavior. Loyal customers to the brand drive advocacy behavior where they tell their families and friends about the value attached in the product or service. Moreover, customer's emotional attachment and commitment to a brand have a powerful influence on customer loyalty and advocacy. In addition, customer's commitment and trust towards a firm increase their willingness to give favorable recommendations to their colleagues and friends about the service provider. Wali, et al., (2016) described how an effective CRM will 
improve the behavioral and attitudinal commitment of customers, leading to loyalty towards the organization's offerings. Firms that develop pleasant relationships with their customers by frequently modifying products and services according to their preferences will attain high degree of customer commitment. Padmavathy et al. (2012) describe CRM as a group of activities directed towards the customer and initiated at strategic level of the organization and based on technology aiming at improving interaction with customer to achieve customer loyalty and thus improving long term profits. According to Nyadzayo and Khajehzadeh (2016); Law, et al., (2018) CRM is based on creating and improving the relationship with customers in the most efficient way to keep them loyal and loyal customers are profitable.

Sota, et al. (2019) stated that due to the competitive business environment in the hotel industry nowadays, CRM has become a crucial tool that every hotel should use to survive in the market. Organizations that implement efficient CRM strategy will obtain several benefits in terms of increasing sales through better understanding of the target segment, personalizing products and services, and most importantly ensuring customer retention and loyalty and loyal customers are much more profitable to the business than new customers as they cost less. Hassanien and Dale, (2019) said that in order to guarantee customer retention through the use of CRM, there should be a continuous contact from the hotel side to keep customers updated by any new services as they might be interested in these services and stay longer in the hotel. Furthermore, customer's own privacy is respected as the hotel policy is based on preventing any potential problems regarding customer's secrecy.

However, Malonza and Lucy (2016) have argued that in the hotel industry, it is not guaranteed that customers will always come back to the same hotel. Therefore, CRM in hotels focuses on developing strong long-term relationships with each customer to try to keep them coming back regularly; that is to increase their loyalty. The target of CRM is to align customer strategies and needs with the business process to gain long-term customer loyalty which will lead to higher retention thus increased profitability. 
From the above review the authors set forth the following hypotheses:

$\mathbf{H}_{\mathbf{a} 3}$ : There is positive significant direct effect of CRM on Customer loyalty

\subsection{Customer Perceived Value (CPV)}

According to Gumussoy and Koseoglu (2016), perceived value refers to the difference between the money actually paid for the product/service and the amount that the customer wants to pay. Perceived value has a major role in enhancing customer satisfaction in the hospitality industry. Mohajerani and Miremadi (2013) stated that perceived value was explained as customer's overall evaluation of the product/service advantages which is mainly established on customer's perception of what is obtained and what is offered. CPV cannot be separated from customer perceived quality of the service rendered to the customer because customer weighs what he gets (quality of service) versus what he pays (price of the service). Nyadzayo and Khajehgzadeh, (2016) state that value will be produced through a trade-off between the sacrifices and benefits and thus an organization should try to correctly determine customer's anticipations and to offer the service at a level which will meet those anticipations. Long, et al (2013) claimed that quality service can be used as a positive indicator for the company to justify value to generate more loyal and satisfied customers which will lead to more profit for the firm. Abdullah, et al., (2016) pointed out that platforms of online booking enable customers to compare hotel prices and booking rooms at the lowest price. Monetary benefits are perceived as an economic value that reliefs a category of customers and enhances their satisfaction. Nyadzayo and Khajehzadeh (2016) stated that customers who have a positive image of a service business (restaurant) are more likely to perceive it as a good value for their money which increase their satisfaction and loyalty. Therefore, a service image has a great impact on customer perceived value, which in turn will affect their satisfaction and loyalty towards the brand. According to Alrawadieh, et al., (2019), many customers are value conscious and value consciousness is a psychological trait where customers constantly seek the market to detect the offerings that best serve their needs and create highest value to them. Kim and Tang, (2020), also add that these value conscious customers constitute a 
segment that is attracted to value based purchases. The impact of CPV increases customer satisfaction and positive attitude when customers are more aware of the various offers available on the market. As such hotels or other service providers try to associate a package of advantages or benefits that they present to customer with the needs and expectations of the customer in order to succeed in attracting the customer and in gaining their satisfaction and loyalty. Value consciousness has a great impact on customers' satisfaction and can detect customer's loyalty (Abadi, et al., 2020).

From the review of literature, the researchers pinpointed a gap in literature which is that although many studies have investigated the impact of CPV on customer satisfaction and loyalty yet none according to the authors' humble knowledge have investigated the mediation role of CPV between CRM and its alleged outcomes of satisfaction and loyalty and this leads to the contribution of this study. Thus the authors assumed that the increase in CPV will change the effects of CRM on customer satisfaction and customer loyalty so they set forth the hypotheses related to the mediation role of CPV between CRM and its alleged outcomes of customer satisfaction and loyalty to test the indirect effects of CRM on Customer Satisfaction, Loyalty via CPV as follows:

Hb1: There is positive significant indirect effect of CRM on Satisfaction via CPV.

$\mathbf{H}_{\mathbf{b} 2:}$ There is positive significant indirect effect of CRM on Loyalty via CPV.

This indirect effect of CRM on Satisfaction and Loyalty via CPV have led to the following hypotheses of total effect as follows:

Hc1: There is positive significant total effect of CRM on Customer Satisfaction

$\mathbf{H}_{\mathbf{c} 2}$ : There is positive significant total effect of CRM on Loyalty

\section{THE CONCEPTUAL MODEL}

From the previous review of literature, the authors set forth the following conceptual model which includes 4 constructs which are CRM, $\mathrm{CPV}$, Customer Satisfaction and Customer Loyalty that were defined in section two. As previously mentioned, the authors hypothesized that CPV 
mediates the relation between CRM and its 2 outcomes of satisfaction and loyalty which is depicted in the following model:

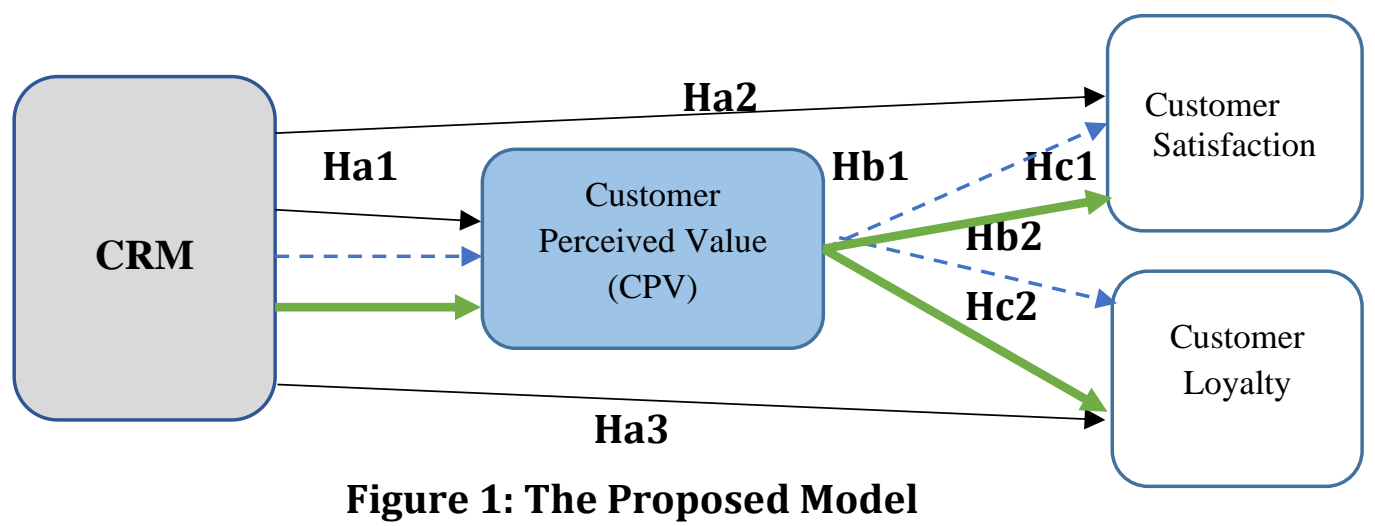

\section{METHODOLOGY}

The researchers resorted to a quantitative research approach as this method was the most suitable as it involves the empirical investigation to answer the research questions. The quantitative approach was appropriate as it served the objective of the research, which was to discover to what extent CRM affects customer satisfaction and loyalty on one hand and to measure the mediation role of CPV on the other hand.

\subsection{Population and Sampling}

The research population includes the guests (people) who stayed at the Four Seasons Hotel with its various branches in Egypt, based on a case study approach. According to Crowe et al., (2011) case studies are less costly and less time-consuming; they are advantageous when exposure data is expensive or hard to obtain, which is the case here. Moreover, few hotels in Egypt apply CRM and they are mainly 5 star hotels, thus the researchers had to resort to a case study approach. The population frame is unavailable and exact figures are almost impossible to access. As such the authors had to resort to a convenient sample from which results have to be treated cautiously yet they could give acceptable and useful insights and results and moreover, these non-probability sampling techniques are heavily used in a wide range of social sciences researches where accessibility to random samples are practically impossible to apply. Convenience sampling is a type of non- probability sampling technique where respondents are selected due to their availability or accessibility or their readiness to answer a questionnaire which saves time, effort and budgetary financial funds, yet can offer valuable facts (Emerson, 2015) As for the sample size according to Hair et al., (2010) the previously used 
guidelines of 300 units sample size are no longer needed when conducting Structural Equation Modeling (SEM) and he suggested that the minimal sample size of 100-150 for models containing 4-7 constructs as such the researchers wanted to distribute 200 questionnaires in order to ensure having 150 COMPLETED questionnaires but only 190 could be distributed within 3 branches of the Hotel.

\subsection{Data Collection Process}

Data was collected using convenient sampling technique where respondents were asked to answer the questionnaire using a face-toface data collection technique. The questionnaire was pilot tested before distributing the final form to the respondents in Arabic and English languages. The researchers ensured that the translation of the questionnaires was correctly undertaken and revised by language specialists. Pilot testing is a small-scale trial, where a few examinees take the test and comment on any problems with the test instructions, instances where items are not clear and formatting and other typographical errors and/or issues (Dikko, 2016). The questionnaires were distributed to customers who have booked a stay at the Four Seasons hotel using convenient sampling technique to guests who accepted to answer the questionnaire, which was a difficult task as the hotel management gave the researchers approval to collect data provided that no customer gets upset and complains. The questionnaire was administered at 3 branches of Four Seasons Residences in Cairo, Giza and Sharm El Sheikh on a case study basis.

150 questionnaires were collected in a complete form out of 190 questionnaires distributed, which makes the response rate $78.9 \%$. The time taken to collect the data was almost 3 weeks including weekends.

\subsection{Sample Characteristics}

Regarding the demographical characteristics of the sample, $48 \%$ of the sample were females, while $52 \%$ were males. For the age distribution, $10.7 \%$ of the respondents were under 20 years, $52 \%$ were between 20 $30,17.3 \%$, between $30-40,12.7 \%$ between $40-50$, and $7.3 \%$ were 50 years and older. Among the samples, $64.7 \%$ were single, $30.7 \%$ were married, $0.7 \%$ were widowed, and $4 \%$ were divorced. Regarding their income level, many respondents refused to answer this question so it was disregarded. 


\section{STATISTICAL ANALYSIS, RESULTS AND EXPLANATION OF RESULTS}

The overall reliability of the questionnaire is $81.5 \%$ which is considered satisfactory to proceed forward with the analysis. In the following subsections the factor analysis statistical technique for data reduction is undertaken. Moreover, there is a statistical summary of measures of the main research variables to test for their significance. Correlation structure is presented to discuss the degree of linear association between pairs of main constructs prior to the structure equation model. A structural equation modeling technique is utilized to test the relationship between CRM and customer satisfaction and customer loyalty via the mediating variable of CPV. The researchers also provide the Construct reliability $\mathrm{CR}$, and the average variance extracted AVE, which are much stronger measures of internal consistency of each construct than Cronbach alpha along with the coefficient of determination. The path analysis is given to verify the proposed research hypothesis.

\subsection{Factor analysis for data reduction}

A factor analysis statistical procedure is implemented in this analysis to select the most reliable and valid items to measure each construct. It is also used to reduce the number of items in each construct to become more effective and to remove redundancy between constructs to avoid any indication of Multicolinearity, which is a common problem in data modeling.

The following Table (1) presents the result of the factor analysis statistical technique with its reliability and variance extracted. 
Table 1: Factor analysis for data Reduction

\begin{tabular}{|c|c|c|c|c|c|}
\hline Constructs & $\begin{array}{l}\text { Factor } \\
\text { loadings }\end{array}$ & $\begin{array}{l}\text { Construct } \\
\text { Mean }\end{array}$ & $\begin{array}{l}\text { Construct } \\
\text { Standard } \\
\text { deviation } \\
\end{array}$ & t-values & $\begin{array}{c}\text { P-value for } \\
\text { testing mean }= \\
3\end{array}$ \\
\hline CRM & & 3.8889 & .64120 & $16.979^{*}$ & 0.000 \\
\hline $\begin{array}{l}\text { The hotel always } \\
\text { keep me in touch } \\
\text { with their new } \\
\text { updates through the } \\
\text { use of technology }\end{array}$ & .534 & & & & \\
\hline $\begin{array}{l}\text { The hotel uses } \\
\text { technology system } \\
\text { to track my opinion } \\
\text { and feed back }\end{array}$ & .506 & & & & \\
\hline $\begin{array}{l}\text { The hotel is willing } \\
\text { to invest in } \\
\text { maintaining a } \\
\text { relationship with } \\
\text { the customer and } \\
\text { tailor their stay }\end{array}$ & .753 & & & & \\
\hline $\mathrm{CPV}$ & & 4.3556 & .54433 & $30.5^{*}$ & 0.000 \\
\hline $\begin{array}{l}\text { I think that I receive } \\
\text { the benefit I expect } \\
\text { in return for the } \\
\text { money I pay }\end{array}$ & .586 & & & & \\
\hline $\begin{array}{l}\text { I believe the hotel } \\
\text { provides an } \\
\text { exceptional level of } \\
\text { service as compared } \\
\text { to the money I pay }\end{array}$ & .561 & & & & \\
\hline $\begin{array}{l}\text { I considered the } \\
\text { hotel pricing policy } \\
\text { as fair and } \\
\text { acceptable }\end{array}$ & .746 & & & & \\
\hline $\begin{array}{c}\text { Customer } \\
\text { Satisfaction }\end{array}$ & & 4.3567 & .57445 & $28.078^{*}$ & 0.000 \\
\hline $\begin{array}{l}\text { I am satisfied with } \\
\text { the quality of the } \\
\text { service that I } \\
\text { received in the hotel }\end{array}$ & .863 & & & & \\
\hline $\begin{array}{l}\text { I am satisfied with } \\
\text { the staff of the hotel }\end{array}$ & .823 & & & & \\
\hline
\end{tabular}




\begin{tabular}{|l|l|l|l|l|l|}
\hline $\begin{array}{l}\text { as they always put } \\
\text { the guest first }\end{array}$ & & & & & \\
\hline \multicolumn{1}{|c|}{ Loyalty } & & 3.7167 & .88123 & $9.96^{*}$ & 0.000 \\
\hline $\begin{array}{l}\text { I am willing to } \\
\text { return the hotel for } \\
\text { another stay }\end{array}$ & .748 & & & & \\
\hline $\begin{array}{l}\text { I would recommend } \\
\text { the hotel to my } \\
\text { friends and family }\end{array}$ & .748 & & & & \\
\hline & & & & & \\
\hline $\begin{array}{l}\text { Overall Reliability } \\
\text { Overall Variance }\end{array}$ & & & \multicolumn{2}{|c|}{ Overall Extracted Variance $=73 \%$} \\
\hline
\end{tabular}

Having identified the most reliable and valid instruments for each construct we express each construct as a weight average of the factor loading and the instruments scores. Table (3) above presents the distribution of the means. It is obvious that the respondents have positive attitude towards the constructs (all p-values $<0.000$ ).

The following Table (2) discusses the degree of association between these constructs.

Table 2: Correlation Structure

\begin{tabular}{|c|l|c|c|c|c|}
\hline \multicolumn{6}{|c|}{ Correlations } \\
\hline \multirow{3}{*}{ CRM } & $\begin{array}{l}\text { Pearson } \\
\text { Correlation }\end{array}$ & 1 & & & \\
& Sig. (2-tailed) & & & & \\
\hline \multirow{3}{*}{ CPV } & $\begin{array}{l}\text { Pearson } \\
\text { Correlation }\end{array}$ & $* 0.63$ & 1 & & \\
\hline & Sig. (2-tailed) & 0.000 & & & \\
\hline \multirow{2}{*}{$\begin{array}{c}\text { Customer } \\
\text { Satisfaction }\end{array}$} & $\begin{array}{l}\text { Pearson } \\
\text { Correlation }\end{array}$ & $* 0.66$ & $* 0.62$ & 1 & \\
\hline & Sig. (2-tailed) & 0.000 & 0.002 & & \\
\hline \multirow{4}{*}{ Loyalty } & $\begin{array}{l}\text { Pearson } \\
\text { Correlation }\end{array}$ & $* 0.65$ & $* 0.56$ & $* 0.78$ & \multirow{2}{*}{1} \\
\hline & Sig. (2-tailed) & 0.000 & 0.000 & 0.000 & \\
\hline \multirow{2}{*}{ * Correlation is significant at the 0.05 level (2-tailed). } \\
\hline
\end{tabular}

As indicated in the table above: CRM has strong positive and significant correlation with CPV $(r=0.63$, P-value $=0.000)$, strong positive and 
significant coloration with Customer Satisfaction $(\mathrm{r}=0.66, \mathrm{p}$-value $=$ $0.000)$, strong positive and significant correlation with Loyalty $(r=0.65$, $\mathrm{p}$-value $=0.000)$.

CPV has strong positive and significant correlation with Customer Satisfaction $(r=62, p$-value $=0.002)$, and has strong positive and significant correlation with Loyalty $(r=0.56$, $p$-value $=0.000)$. Customer Satisfaction has strong positive and significant correlation with Loyalty $(\mathrm{r}=0.78$, $\mathrm{p}$-value $=0.000)$.

\subsection{Measures of Fit of the Model}

The researchers utilized the Structure Equation Modeling technique (SEM) to fit the data to the proposed model (Hair et. al. 2010; Sharma, 1996). Several measures of goodness of fit were considered to test the model. In specific the goodness of fit indices GFI $=0.86$ and the cutoff point is 0.85 or above which is within the accepted level. Moreover, Adjusted Goodness of Fit Index (AGFI) $=0.83$ and the cutoff point is 0.80 or above so again the fit index is accepted.

Root Mean Square Residual $(\mathrm{RMR})=0.052$, Standardized RMR $=.052$, and Hair et al., (2010) suggested 0.05 or less deemed acceptable. Thus these 2 indices are accepted and prove that the model is fit.

Moreover, the ratio of $\chi / \mathrm{df}=366.13 / 105=3.487$, recommended 4 or less. Thus the ratio is in the accepted zone.

From the above fit measures it is clear that the model is fit and could be reused in other hotels.

Having arrived to the fitted model, we can now calculate both the construct reliability (CR) and the average variance extracted (AVE).

Table 3: Composite Reliability and Average Explained Variance

\begin{tabular}{|l|c|c|c|}
\hline \multicolumn{1}{|c|}{ Constructs } & $\begin{array}{c}\text { Composite } \\
\text { Reliability } \\
\text { (CR) }\end{array}$ & $\begin{array}{c}\text { Average } \\
\text { Variance } \\
\text { Explained (AVE) }\end{array}$ & $\begin{array}{c}\text { The Coefficient of } \\
\text { Determination } \\
\text { (R² }^{2}\end{array}$ \\
\hline $\begin{array}{l}\text { Customer Relationship } \\
\text { Management CRM }\end{array}$ & $69.40 \%$ & $53.6 \%$ & - \\
\hline $\begin{array}{l}\text { Customer Perceived } \\
\text { Value CPV }\end{array}$ & $77.16 \%$ & $53.12 \%$ & $40 \%$ \\
\hline Customer Satisfaction & $82.3 \%$ & $60.79 \%$ & $34 \%$ \\
\hline Customer Loyalty & $87.4 \%$ & $55.32 \%$ & $81 \%$ \\
\hline
\end{tabular}


According to Hair et al. (2010) it is recommended that CR to be at least $70 \%$ and the AVE to be at least $50 \%$. As shown in the table almost all constructs satisfy these requirements.

Table 4: Path Analysis and the Justification of Research Hypotheses

\begin{tabular}{|c|c|c|c|c|c|c|}
\hline $\begin{array}{c}\text { Direction of the } \\
\text { Effect }\end{array}$ & $\begin{array}{l}\text { Path } \\
\text { Coef. }\end{array}$ & $\begin{array}{c}\text { Standa } \\
\text { rd } \\
\text { error }\end{array}$ & $\begin{array}{c}\text { t- } \\
\text { value }\end{array}$ & $\begin{array}{c}\text { p- } \\
\text { value }\end{array}$ & $\begin{array}{c}\text { The } \\
\text { significanc } \\
\text { e }\end{array}$ & $\begin{array}{c}\text { The } \\
\text { Hypothese } \\
\text { s }\end{array}$ \\
\hline \multicolumn{7}{|l|}{ The Direct Effect } \\
\hline $\mathrm{CRM} \longrightarrow \mathrm{CPV}$ & 0.63 & 0.13 & 4.81 & 0.000 & $\mathrm{~S}$ & $\mathrm{H}_{\mathrm{a} 1}$ \\
\hline CRM $\longrightarrow$ Satisfaction & 0.44 & 0.16 & 2.71 & 0.003 & $\mathrm{~S}$ & $\mathrm{H}_{\mathrm{a} 2}$ \\
\hline CRM $\longrightarrow$ Loyalty & 0.62 & 0.27 & 2.27 & 0.012 & $\mathrm{~S}$ & $\mathrm{H}_{\mathrm{a} 3}$ \\
\hline \multicolumn{7}{|l|}{ The Indirect Effect } \\
\hline CRM $\longrightarrow$ Satisfaction & 0.33 & 0.11 & 2.94 & 0.002 & $\mathrm{~S}$ & $\mathrm{H}_{\mathrm{b} 1}$ \\
\hline CRM $\longrightarrow$ Loyalty & 0.23 & 0.14 & 1.67 & 0.047 & $\mathrm{~S}$ & $\mathrm{Hb}_{\mathrm{b} 2}$ \\
\hline \multicolumn{7}{|l|}{ The Total Effect } \\
\hline $\mathrm{CRM} \longrightarrow$ Satisfaction & 0.77 & 0.12 & 5.68 & 0.000 & $\mathrm{~S}$ & $\mathrm{H}_{\mathrm{c} 1}$ \\
\hline CRM $\longrightarrow$ Loyalty & 0.85 & 0.13 & 4.25 & 0.000 & $\mathrm{~S}$ & $\mathrm{H}_{\mathrm{c} 2}$ \\
\hline
\end{tabular}

From Table (4) the path analysis above presents path coefficient, its standard error, $t$-value, the $p$-value, and whether the effect is significant or insignificant, and finally the corresponding research hypothesis.

As shown in Table (4):

- CRM has a significant positive direct effect on CPV by 0.63 , which means increasing CRM by one unit will increase CPV by $63 \%$ of a unit thus $\mathrm{H}_{\mathrm{a} 1}$ is supported

- CRM has a significant positive direct effect on Satisfaction by 0.44, which means increasing CRM by one unit will increase Satisfaction by $44 \%$ of a unit thus $\mathrm{H}_{\mathrm{a} 2}$ is supported

- CRM has a significant positive direct effect on Loyalty by 0.62 , which means increasing CRM by one unit will increase loyalty by $62 \%$ of a unit thus $\mathrm{H}_{\mathrm{a}} 3$ is supported

- CRM has a significant indirect effect on Satisfaction via CPV by 0.33 , which means increasing CRM by one unit will increase Satisfaction via CPV by an additional $33 \%$ of a unit thus $\mathrm{H}_{\mathrm{b} 1}$ is supported

- CRM has a significant indirect effect on Loyalty via CPV by 0.14 , which means increasing CRM by one unit will increase Loyalty via CPV by $14 \%$ of a unit thus $\mathrm{Hb}_{\mathrm{b}}$ is supported

Finally if the direct effect is added to the indirect effect via CPV then the total effect will be as follows: 
- CRM has a significant total effect on Satisfaction by 0.77, which means increasing CRM by one unit will increase Satisfaction by $77 \%$ of a unit thus $\mathrm{H}_{\mathrm{c} 1}$ is supported

- CRM has a significant total effect on Loyalty by 0.85 , which means increasing CRM by one unit will increase Loyalty by $85 \%$ of a unit thus $\mathrm{H}_{\mathrm{c} 2}$ is supported (Pant, et al.,2020); (Wang, Y., \& Feng, H. 2012).

\subsection{The Role of Mediation}

There is $33 \%$ positive and significant indirect effect of CRM on customer perceived satisfaction, and, $23 \%$ indirect positive and significant effect of CRM on loyalty. These findings signify that CPV plays a role in enhancing the relationship between CRM and Customer satisfaction and customer loyalty. Thus the mediation effect strengthens the relationship between independent variable (predictor) CRM and its alleged outcomes of customer satisfaction and loyalty (dependent variables).

\section{DISCUSSION}

In conclusion, the analysis proves that CRM has a positive significant direct impact on Customer Satisfaction just as Madhovi and Dhliwayo (2017) indicated that when hotel managers implement CRM which, provides customization services for the customers, it will ensure satisfaction. This was also stated by Kumar, (2020). Ruiz-Martínez, et al., (2019) who ensured that the main aim of building a relationship with customers is to ensure satisfaction of the customers as satisfied customers will rarely think about switching from one company to another and are less susceptible to price connected service facilities and progressively turn into a center for generation of revenue (Al-Weshah, et al., 2019). Moreover, the findings ensure that CRM has a positive significant direct impact on Customer Loyalty and this aligns with (Nyadzayo and Khajehzadeh 2016); (Law, et al., 2018) that CRM which is based on creating and improving the relationship with customers in the most efficient way to keep them loyal. Moreover, Ong, et al., (2018) added that the extremely tough competition in the hospitality industry emphasizes creating a very good relationship with the profitable customers which is ensured through CRM activities that will lead to brand loyalty. 
Furthermore, the analysis assures that CRM has a positive significant indirect impact on Customer satisfaction and customer loyalty through CPV thus CPV mediates the relationship between CRM and its alleged outcomes of satisfaction and loyalty. This aligns with Alrawadieh, et al., (2019); Kim and Tang, (2020); Abadi, et al., (2020) who explain that value conscious customers constitute a segment that is attracted to value-based purchases. Thus the impact of CPV plays an important role in customer satisfaction and loyalty. In fact, in today's world of tight economic conditions customers tend to weigh the benefits they receive with the money that they pay, even for affluent customers and the high exposure of the internet allows for customers easier comparisons in prices. Our findings indicate that CPV plays a role in enhancing the relationship between CRM and customer satisfaction and customer loyalty. Thus the mediation effect strengthens the relationship between independent variable (predictor) CRM and its alleged outcomes of customer satisfaction and loyalty (dependent variables). Thus, the research contributes to practitioners by pinpointing the organization benefits of using the CRM with clearly understanding the CPV in order to cross-sell other company products to the selected customers, target them personally.

Thus all results align with the findings of the literature and it can quite safely be concluded that CRM is actually worth the money spent as it leads to favorable outcomes of customer satisfaction and loyalty are mandatory to achieve profitability and that CPV adds to customer satisfaction and loyalty which are what the hospitality industry aims at to achieve profits and success.

\section{ACADEMIC AND MANAGERIAL IMPLICATIONS}

This study contributes to the existing literature through providing a comprehensive understanding of different aspects of CRM that include different points of view about what CRM is and dimensions of CRM and implication of CRM. Moreover, this study investigates the mediation role of CPV which strengthens the outcomes of CRM (satisfaction and loyalty).

As for the practical managerial implications that could shed light to managers of hotels that apply or are in the plan of applying CRM in hotels in Egypt the following recommendations were compiled based on the conducted study: 
- It is essential that senior management of Egyptian hotels especially 5 star hotels employ tailored service, based on the data collected by the CRM system about clients at all touch point (as the website, Facebook, Twitter, as well as previous stay and other) to understand their detailed needs and tailor the service, consequently this customized provision will enhance the quality of service offered by the hotel which would turn satisfied customers into loyal customers. Thus CRM systems if well managed are worth the money invested in them.

- If the hotel is in a holiday resort overlooking the sea, where local Egyptian guests are the majority, then as concluded from the findings that CRM practices have an impact on CPV, thus management should keep customers in touch with any new updates as off season saving packages that could encourage customers to attempt to take an extra visit that was not planned; or, inform customers with high season extra additions that enhance the customer experiences and increases CPV as free SPA or free massage or outdoor marathon, or children events as treasure hunting or any other event that would enrich the visitation experience. Informing customers and keeping them updated of all packages, attractions, events or extras tailored to customer creates a closer relationship with customers.

- As for city center hotels, where there is usually no off-season, managers should use their data-base as nationality of guests to try and tailor cultural differences in food and customs and traditions of visitors. Example, in downtown hotel branches where Arab guests are more in number the hotel should accommodate big family rooms or conjunction rooms to serve bigger families. Moreover, events as entertained dinner should start later than for European dinner hours as Arabs prefer late evening events. Furthermore, European guests are more after sightseeing tours, while Arab guests usually tend to prefer internal entertainment that require more employee creativity, effort and professional service as sauna, indoor pool, GYM, kids play area and other. Added to this is the variety of oriental and continental food meals to satisfy all tastes whether Europeans or Arabs. All the information needed to create tailored services could only be achieved through CRM system.

\section{RESEARCH LIMITATIONS}

This study is conducted in three branches of one international hotel in Egypt as a case study and just like any case study, it has the dangerous limitation which is that results can't be generalized. Moreover, according 
to Crowe, et.al, (2011) case studies are subject to selection bias. This research gives us insight into the topic under investigation which is a very important concept in modern marketing which is CRM. Although the fit measures of the model prove to be acceptable yet they are border line thresholds and this invites further research as the model needs to be reinvestigated on other hotels within Egypt whether they are downtown located or seaside resorts.

The results of the research were based on a limited survey that has been distributed in three hotel branches located in Egypt the Four Seasons one in Garden City and the other is in Giza and third near the Red Sea. It is advisable that further researches at different hotels are necessary to establish the exact nature of the linkages between CRM and CPV and then assess the impact of such concepts on customer satisfaction and loyalty. Thus the model could be further tested on other hotels in Egypt.

\section{SUGGESTIONS FOR FUTURE RESEARCH}

Law et al. (2018) states that minimal academic research was undertaken to investigate the adverse aspects of CRM and thus, this could be considered as an area for future research. Moreover, according to Edinger, (2018) around one third of CRM projects fail, thus CRM could have its problems and this requires investigation. The failure is caused by the fact that CRM practices are used for monitoring and reporting rather than for attracting new sales, thus there is an unrealistic shadow interest in building a relationship with customers and the main concern of applying CRM is data entry about customers which leads to invading customer privacy and annoying customers with intrusion and burdens the organization with unnecessary expenses.

Furthermore, Sota, et al. (2019) note that nearly none of the articles handling CRM have analyzed the impact of CRM on new customer generation which is critical, taking into consideration that international hotels are spending millions of dollars on CRM systems yearly and as such there is a need to investigate accurately the specific cost benefit analysis of CRM in hospitality industry.

\section{REFERENCES}

Abadi, R. R.; Nursyamsi, I., \& Syamsuddin, A. R. (2020). Effect of Customer Value and Experiential Marketing to Customer Loyalty with Customer Satisfaction as Intervening Variable (Case Study on Gojek Makassar Consumers). The Asian Journal of Technology Management, 13(1), 82-97. 
Abbasi, S. A.; Azam, M.; Khalid, W., \& Riaz, A. (2010). Determinants of customer satisfaction in hotel industry of Pakistan. European Journal of Scientific Research, 48(1), 97-105.

Abdullah, D.; Jayaraman, K., \& Kamal, S. B. M. (2016). A conceptual model of interactive hotel website: The role of perceived website interactivity and customer perceived value toward website revisit intention. Procedia Economics and Finance, 37, 174

Abdullah, D.; Kamal, S. B. M.; Azmi, A.; Lahap, J.; Bahari, K. A.; Din, N., \& Pinang, C. P. (2019). Perceived Website Interactivity, Perceived Usefulness and Online Hotel Booking Intention: A Structural Model. Malays. J. Consum. Fam. Econ, 21, 45-57.

Agag, G. M.; Khashan, M. A.; Colmekcioglu, N.; Almamy, A.; Alharbi, N. S.; Eid, R., \& Abdelmoety, Z. H. S. (2019). Converting hotels website visitors into buyers: How online hotel web assurance seals services decrease consumers' concerns and increase online booking intentions. Information Technology \& People.

Ahmed, B. S.; Amroush, F., \& Maati, M. B. (2019). The Intelligence of ECRM Applications and Approaches on Online Shopping Industry. In Advanced Methodologies and Technologies in Digital Marketing and Entrepreneurship (70-82). IGI Global.

Ahmed, R. R.; Vveinhardt, J.; Warraich, U. A.; Hasan, S. S. U., \& Baloch, A. (2020). Customer satisfaction \& loyalty and organizational complaint handling: economic aspects of business operation of airline industry. Engineering Economics, 31(1), 114-125.

Alrawadieh, Z.; Prayag, G.; Alrawadieh, Z., \& Alsalameen, M. (2019). Selfidentification with a heritage tourism site, visitors' engagement and destination loyalty: the mediating effects of overall satisfaction. The Service Industries Journal, 39(7-8), 541-558.

Al-Weshah, G. A.; Al-Manasrah, E., \& Al-Qatawneh, M. (2019). Customer relationship management systems and organizational performance: Quantitative evidence from the Jordanian telecommunication industry. Journal of Marketing Communications, 25(8), 799-819.

Avelini Holjevac, I.; Marković, S., \& Raspor, S. (2009). Customer satisfaction measurement in hotel industry: content analysis study.In $4^{\text {th }}$ International Scientific Conference" Planning for the 
future learning from the past: Contemporary Developments in Tourism, Travel \& Hospitality".

Banki, M. B.; Ismail, H. N. B.; Danladi, M. H., \& Dalil, M. (2016). Measuring hotels service quality in Nigeria: A case study of Minna Townshio. Journal of Quality Assurance in Hospitality \& Assurance, 17(1), 7188.

Bufquin, D.; Park, J. Y.; Back, R. M.; Nutta, M. W., \& Zhang, T. (2019). Effects of hotel website photographs and length of textual descriptions on viewers' emotions and behavioral intentions. International Journal of Hospitality Management, 102378

Crowe, S.; Cresswell, K.; Robertson, A.; Huby, G.; Avery, A., \& Sheikh, A. (2011). The case study approach. BMC Medical Research Methodology, 11(1), 100.

Dewnarain, S.; Ramkissoon, H., \& Mavondo, F. (2018). Social customer relationship management: An integrated conceptual framework. Journal of Hospitality Marketing \& Management, 28(2), 172-188.

Dikko, M. (2016). Establishing construct validity and reliability: Pilot testing of a qualitative interview for research in Takaful (Islamic insurance). The Qualitative Report, 21 (3), 521-528.

Dominici, G., \& Guzzo, R. (2010). Customer satisfaction in the hotel industry: a case study from Sicily. International Journal of Marketing Studies, 2(2), 3-12.

Edinger,S.(2018). Why CRM projects fail and how to make them more successful. Harvard Business Review.

El Deeb, M. S., \& Halim, Y. T. (2010) A Balanced Scorecard Model to Align Performance Evaluation of Egyptian Hospitality Organizations. The Journal of Accounting, Management, and Insurance,14. Cairo University, Faculty of Commerce. Available at SSRN 1874932

El Sheikh, S. (2019). How engaged customers can help the brand: an empirical case study on a higher education institution (university) in Egypt. International Journal of Marketing Studies, 11(1), 85-100.

Emerson, R. W. (2015), Convenience sampling, random sampling, and snowball sampling: How does sampling affect the validity of research? Journal of Visual Impairment and Blindness (Online), 109 (2), 164-180. 
Emir, A.; Halim, H.; Hedre, A.; Abdullah, D.; Azmi, A., \& Kamal, S. B. M. (2016). Factors influencing online hotel booking intention: A conceptual framework from stimulus-organism-response perspective. International Academic Research Journal of Business and Technology, 2(2), 129-134.

Fakharyan, M.; Omidvar, S.; Khodadadian M. R.; Jalilvand, M. R. \& Vosta, L. N. (2014). Examining the effect of customer-to-customer interactions on satisfaction, loyalty, and word-of-mouth behaviors in the hospitality industry: the mediating role of personal interaction quality and service atmospherics. Journal of Travel and Tourism Marketing, 31(5), 610-626.

Gremler, D. D.; Van Vaerenbergh, Y.; Brüggen, E. C., \& Gwinner, K. P. (2019). Understanding and managing customer relational benefits in services: a meta-analysis. Journal of the Academy of Marketing Science, 1-19.

Gumussoy, C. A., \& Koseoglu, B. (2016). The effects of service quality, perceived value and price fairness on hotel customers' satisfaction and loyalty. Journal of Economics, Business and Management, 4(9), 523-527. http://www.joebm.com/vol4/446MM0015.pdf

Hair, J.; Black, W.; Babin, B., \& Anderson, R. (2010). Multivariate Data Analysis: A Global Perspective, $7^{\text {th }}$ edition, Pearson Prentice Hall: New Jersey.

Halim, Y.T. and Halim, H.T., (2013). Guest Satisfaction and Hotel Profitability in Egypt. Journal of Association of Arab Universities for Tourism and Hospitality, 10 (1).June.

Hassanien, A., \& Dale, C. (2019). Hospitality business development. Routledge.

Hislop, D.; Bosua, R., \& Helms, R. (2018). Knowledge management in organizations: A critical introduction. Oxford University Press.

Hollebeek, L. D.; Srivastava, R. K., \& Chen, T. (2019). SD logic-informed customer engagement: integrative framework, revised fundamental propositions, and application to CRM. Journal of the Academy of Marketing Science, 47(1), 161-185.

Hu, X. S., \& Yang, Y. (2019). Determinants of consumers' choices in hotel online searches: A comparison of consideration and booking stages. International Journal of Hospitality Management, 102370. 
Itani, O. S.; Kassar, A. N., \& Loureiro, S. M. C. (2019). Value get, value give: The relationships among perceived value, relationship quality, customer engagement, and value consciousness. International Journal of Hospitality Management, 80, 78-90.

Kim, E., \& Tang, L. R. (2020). The role of customer behavior in forming perceived value at restaurants: A multidimensional approach. International Journal of Hospitality Management, 87, 102511.

Khodakarami, F., \& Chan, Y. E. (2014). Exploring the role of customer relationship management (CRM) systems in customer knowledge creation. Information \& Management, 51(1), 27-42.

Kotler \& Armstrong (2017). Principles of Marketing, 17th edition: Pearson Prentice Hall: New Jersey.

Kumar, V. (2020). Building Customer-Brand Relationships through Customer Brand Engagement. Journal of Promotion Management, 1-27.

Kurnia, G., \& Sulistiani, P. B. (2019). Influencing consumer's behavior: perspective of information quality and consumers' reviews on airy-rooms. People: International Journal of Social Sciences, 5(1).

Law, R.; Fong, D.K.C.; Chan, I. C. C., \& Fong, L. H. N. (2018). Systematic review of hospitality CRM research. International Journal of Contemporary Hospitality Management, 30(3), 1686-1704. DOI: 10.1108/IJCHM-06-2017-0333.

Leong, L. Y.; Hew, T. S.; Ooi, K. B., \& Lin, B. (2019). Do electronic word-ofmouth and elaboration likelihood model influence hotel booking. Journal of Computer Information Systems, 59(2), 146-160.

Long, C. S.; Khalafinezhad, R.; Ismail, W. K. W., \& amp; Rasid, S. Z. A. (2013). Impact of CRM factors on customer satisfaction and loyalty. Asian Social Science, 9(10), 247.

Madhovi, P. G., \& Dhliwayo, S. (2017). The relationship between customer relationship management (CRM) and performance in the hotel industry. African Journal of Hospitality, Tourism and Leisure, 6(1), 1-13.

Malonza, R., \& Lucy, J. (2016). Effectiveness of Customer Relationship Management in the Hotel Industry in Eldoret Town, Kenya. International Journal of Science and Research, 5(12), 2125-2128. 
Mohajerani, P., \& Miremadi, A. (2013). Exploring Two Main Perspectives towards Customer Satisfaction in hotel industry: Managers and Customers. International Journal of Academic Research in Business and Social Sciences, 3(9), 245.

Mohammed, A; Rashid, B. (2012). Customer Relationship Management (CRM) in Hotel Industry: A framework Proposal on the Relationship among CRM Dimensions, Marketing Capabilities, and Hotel Performance. International Review of Management and Marketing, 2 (4), 220-230.

Monga, M. N., \& Kaplash, M. S. (2016). To Study Consumer Behavior while booking Hotel through Online Sites. International Journal of Research in Economics and Social Sciences, 6(5), 158-164.

Munandar, J. M.; Oktaviani, D., \& Angraini, Y. (2020). How important is CRM toward customer's loyalty to conventional and Islamic bank marketing strategy? Journal of Islamic Marketing. https://doi.org/10.1108/JIMA-07-2019-0146

Nazir, S.; Khan, S.; Jamil, R. A.; \& amp; Mehmood, Q. S. (2014). Impact of customer relationship management on customer satisfaction in hoteling industry. Journal of Management Info, 3(1), 84-98.

Nyadzayo, M. W., \& Khajehzadeh, S. (2016). The antecedents of customer loyalty: A moderated mediation model of customer relationship management quality and brand image. Journal of Retailing and Consumer Services, 30, 262-270.

Ong, C. H.; Lee, H. W., \& Ramayah, T. (2018). Impact of brand experience on loyalty. Journal of Hospitality Marketing and Management, 120.

Pandey, P. (2012). The Relationship between CRM Dimensions and Customer Retention in Indian Banking Industry: An Empirical Study of Public and Private Sector Bank. Journal of Commerce and Accounting Research, 1(4), 51.

Pant, M.; Virdi, A. S., \& Chaubey, D. S. (2020). Examining the effect of marketing innovations on GPMA: A study using the PLS-SEM Approach. Global Business Review, 21(4), 1025-1036.

Rahimi, R. (2017). Customer relationship management (people, process and technology) and organizational culture in hotels: Which traits matter? International Journal of Contemporary Hospitality Management, 29(5), 1380-1402. 
Ruiz-Martínez, A.; Frasquet, M., \& Gil-Saura, I. (2019). How to measure B2B relationship value to increase satisfaction and loyalty. Journal of Business \& Industrial Marketing, 34(8), 1866-1878.

Saleem, H., \& Raja, N. S. (2014). The impact of service quality on customer satisfaction, customer loyalty and brand image: Evidence from hotel industry of Pakistan. Middle-East Journal of Scientific Research, 19(5), 706-711.

Sofi, M. R.; Bashir, I.; Parry, M. A., \& Dar, A. (2020). The effect of customer relationship management (CRM) dimensions on hotel customer's satisfaction in Kashmir. International Journal of Tourism Cities.

Sota, S.; Chaudhry, H.; Srivastava, M. K. (2019). Customer relationship management research in hospitality industry: a review and classification. Journal of Hospitality Marketing and Management, 1-26. DOI: 10.1080/19368623.2019.1595255.

Wali, A. F.; Uduma, I. A., \& Wright, L. T. (2016). Customer relationship management (CRM) experiences of Business-to-Business (B2B) marketing firms: A qualitative study. Cogent Business \& Management, 3(1), 1183555.

Wang, Y., \& Feng, H. (2012). Customer relationship management capabilities: Measurement, antecedents and consequences. Management Decision, 50(1), 115-129. Emerald Group Publishing Limited

Yen, C. L. A., \& Tang, C. H. H. (2015). Hotel attribute performance, e-WOM motivations, and media choice. International Journal of Hospitality Management, 46, 79-88. 


\section{ملخص البحث باللفة العربية}

تدرك العديد من الشركات ومقدمي الخدمات، بما في ذلك الفنادق، أهمية إدارة علاقات العملاء (CRM) وقدرتها على مساعدتهم في اكتساب عملاء جدد والاحتفاظ بالعملاء الحاليين وزيادة القيمة إلى أقصى حد.

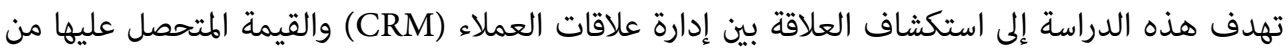

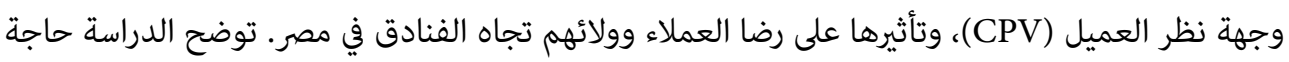

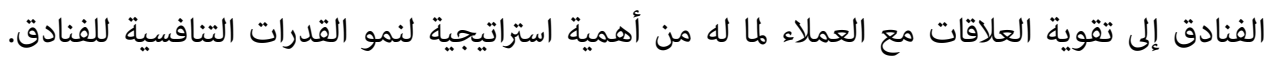

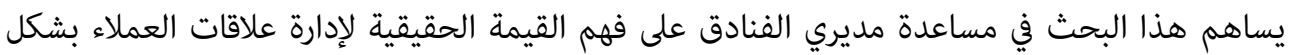

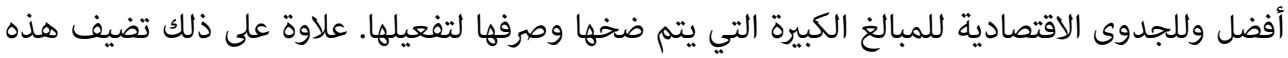

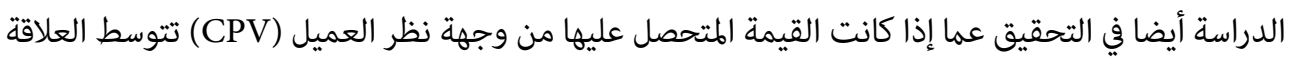
بين إدارة علاقات العملاء (CRM) ورضا / ولاء العملاء أم لا. اعتمد الباحثون منهجا كميا بدأ بمراجعة شاملة التهات للأدبيات لففهوم إدارة علاقات العملاء (CRM) ونتائجها على القيمة المتحصل عليها من وجهة نظر العماء العميل

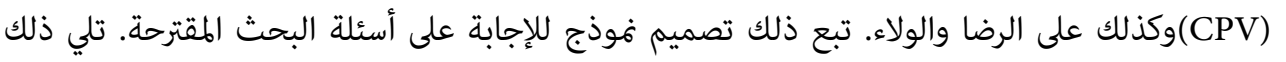

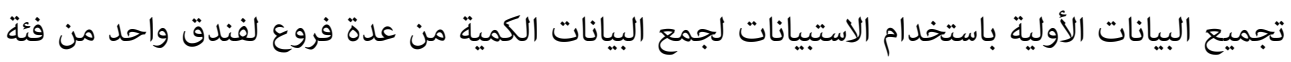

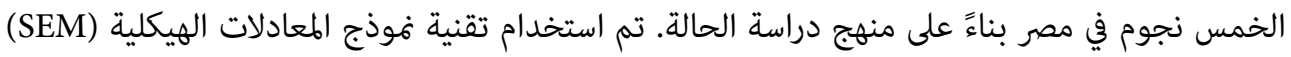
لتأسيس العلاقة السبية بين إدارة علاقات العملاء (CRM) ورضا العملاء وولائهم من خلال منال المتغير الوسيط

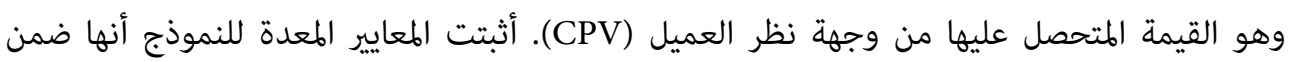

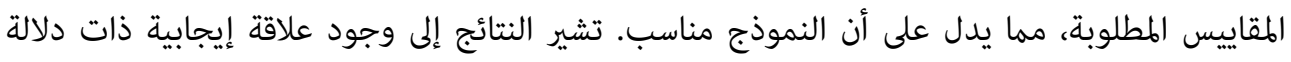
إحصائية بين CRM و CPV وأن CRM يؤثر بشكل إيجابي على رضا العملاء وولائهم، ومع ذلك يقترح الباحثون التطبيق على فنادق الأخرى لإجراء مزيد من الاختبارات على النموذج المقترح. الكلمات المفتاحية: رضا العملاء -القيمة المتحصل علها من قبل العميل- إخلاص العملاء - تحليل المسار

\section{Suggested Citation according to APA Style}

El Sheikh, S.; Halim, Y.; Hamdy, H. and Hamdy, M. (2020). The Impact of CRM on Customer Satisfaction and Customer Loyalty: Mediation Effect of Customer Perceived Value (Evidence from Hospitality Industry). Journal of Alexandria University for Administrative Sciences, Faculty of Commerce- Alexandria University 57(4), 87 120. 